\title{
Faktor Penentu Prestasi Pelajar Matrikulasi dalam Subjek Perakaunan
}

\author{
ZUAINI ISHAK \\ NOR AZIAH ABDUL MANAF \\ ROSLIZA MAT ZIN
}

Universiti Utara Malaysia

\begin{abstract}
Abstrak: Kajian ini bertujuan mengenal pasti faktor-faktor yang menentukan prestasi pelajar dalam subjek perakaunan di peringkat matrikulasi. Berdasarkan 450 soal selidik yang dikeluarkan, analisis kajian ke atas 393 sampel yang boleh digunakan menunjukkan purata gred pelajar secara keseluruhannya berada dalam lingkungan C. Penemuan kajian dengan menggunakan kaedah "stepwise" regresi berkali, menunjukkan hubungan positif yang signifikan antara markah perakaunan pengurusan dengan purata mata gred keseluruhan dan pencapaian bagi subjek perakaunan kewangan yang diambil oleh pelajar dalam semester sebelumnya. Di samping itu, sikap, jangkaan tahap motivasi dan jangkaan markah menunjukkan hubungan yang signifikan dengan prestasi pelajar. Bagaimanapun, dapatan kajian telah menunjukkan bahawa pelajar yang tidak mempunyai pendedahan awal dalam subjek perakaunan menunjukkan prestasi yang lebih baik berbanding dengan mereka yang mempunyai pendedahan awal dalam subjek perakaunan.
\end{abstract}

\begin{abstract}
This study explores the determinants of students' performance in accounting at the matriculation level. Out of 450 questionnaires distributed, analysis on the 393 usable sample shows the overall average students' grade point is at the range of C. Using stepwise multiple regression, the findings show significant positive relationships between the grade of management accounting subject with the previous cumulative grade point average and the achievement in financial accounting subject that was taken in the previous semester. Besides that, attitude, motivation and expected marks show significant relationships with the students' performance. Interestingly, the results show that students without accounting exposure perform better than those with previous accounting exposure.
\end{abstract}




\section{PENGENALAN}

Program Matrikulasi Kementerian Pendidikan Malaysia merupakan salah satu saluran yang disediakan untuk kemasukan pelajar-pelajar ke peringkat ijazah di universiti awam tempatan. Bilangan pelajar lepasan matrikulasi yang diterima masuk ke universiti adalah besar berbanding lepasan Siji Pengajian Tinggi Malaysia (STPM) dan Diploma. Sebagai contoh, untuk kemasukan pelajar peringkat ijazah bagi sesi Julai 2007/08, sebanyak 62\% pelajar yang diterima masuk terdiri daripada program matrikulasi. Prestasi pelajar di peringkat matrikulasi penting bagi membolehkan pelajar mengikuti program pilihan mereka di peringkat ijazah. Program perakaunan merupakan salah satu program utama yang ditawarkan sejak awal program matrikulasi diperkenalkan. Pada masa kini, selain daripada program perakaunan, program undang-undang juga menghendaki pelajar mengambil empat subjek wajib termasuk subjek perakaunan. Walau bagaimanapun, kebanyakan pelajar sukar untuk mendapat prestasi yang baik dalam subjek perakaunan.

Terdapat banyak kajian terdahulu telah dijalankan dalam mencari punca atau faktor yang mempengaruhi prestasi akademik pelajar. Menurut Richter (2006), prestasi terdahulu pelajar semasa di peringkat sekolah menengah merupakan antara penentu utama bagi prestasi mereka apabila mengikuti program pentadbiran perniagaan di peringkat ijazah. Selain daripada faktor prestasi terdahulu, faktor yang dikenalpasti dalam kajian-kajian lain ialah pendedahan awal atau pengetahuan dalam subjek dan subjek berkaitan. Ciri-ciri diri seperti sikap, usaha dan motivasi juga dapat mempengaruhi prestasi pelajar. Faktor luaran seperti galakan oleh keluarga merupakan faktor penentu prestasi yang signifikan. Di samping itu, kajian lain yang menilai prestasi pelajar secara umum telah dijalankan oleh Birch dan Miller (2007). Kajian dalam bidang sistem maklumat dilakukan oleh Kruck dan Lending (2003); pentabiran perniagaan (Richter, 2006); matematik (Papanastasiou, 2000); dan ekonomi (Borg dan Stranahan, 2002). Selain itu, kajian dalam bidang pendidikan perakaunan yang dijalankan oleh Maksy dan Lin Zheng (2008); Waples dan Darayseh (2005); Davidson (2002); McKenzie \& Schweitzer (2001); Wooten (1998); Turner, Holmes dan Wiggins (1997); Gist dan Goedde (1996); Ibrahim (1989); Eskew dan Faley (1988); Delaney, Keys, Norton dan Simon (1979); Hicks dan Richardson (1984), Baldwin dan Howe (1982) menunjukkan terdapat beberapa faktor yang mempunyai hubungan signifikan dengan prestasi pelajar. Namun, kajian-kajian yang dijalankan di 
negara barat mempunyai sistem pendidikan dan budaya yang agak berbeza dengan sistem dan kaedah pendidikan di Malaysia.

Pengajian di peringkat matrikulasi ditawarkan kepada para pelajar yang terpilih dan cemerlang di peringkat Sijil Pelajaran Malaysia (SPM). Namun, prestasi pelajar di peringkat matrikulasi tidak diberi tumpuan dalam kajian terdahulu. Kajian ini dijalankan bagi menilai prestasi pelajar matrikulasi dalam subjek perakaunan memandangkan prestasi pelajar dalam subjek ini kurang memuaskan. Kajian ini penting bagi mengenal pasti faktor-faktor yang menentukan prestasi pelajar dalam subjek perakaunan dan memahami mengapa sebahagian pelajar memperoleh pencapaian yang rendah dalam subjek ini sedangkan mereka merupakan pelajar-pelajar yang terpilih untuk mengikuti program matrikulasi. Faktor-faktor yang didapati mempengaruhi prestasi pelajar yang diperoleh daripada kajian terdahulu diambilkira dalam kajian ini. Berbanding dengan kajian terdahulu yang dijalankan di barat, kajian ini mengambil kira situasi pelajar di Malaysia. Dua pemboleh ubah baru yang diambilkira ialah sekolah terakhir pelajar dan juga jangkaan program yang diikuti pelajar di peringkat ijazah. Dapatan kajian ini diharapkan dapat membantu para pelajar, guru dan pihak pentadbiran program matrikulasi bagi mengenal pasti punca kelemahan. Disamping dapat menentukan langkah-langkah pembetulan seperti penyediaan kurikulum dan kaedah pengajaran yang berkesan, menetapkan polisi pengambilan pelajar dan prasyarat kursus yang bersesuaian untuk meningkatkan mutu pencapaian pelajar dalam subjek perakaunan.

\section{Prestasi Akademik Terdahulu}

Banyak kajian yang dijalankan sebelum ini mendapati prestasi terdahulu merupakan faktor utama dalam menentukan prestasi pelajar. Kajian Richter (2006) mendapati prestasi di peringkat sekolah merupakan faktor utama menentukan kejayaan pelajar di peringkat universiti. Waples dan Daraiseh (2005); dan Didia dan Hasnat (1998) merumuskan prestasi terdahulu dalam subjek-subjek berkaitan mempunyai hubungan dengan prestasi dalam subjek tertentu. Kajian Gist dan Goedde (1996) dan Eskew dan Faley (1988) menunjukkan subjek matematik dan kalkulus mempunyai hubungan yang signifikan dengan prestasi pelajar dalam subjek perakaunan. Dapatan kajian oleh Didia dan Hasnat (1998) menunjukkan prestasi yang baik dalam subjek-subjek asas perakaunan, ekonomi dan matematik mempunyai hubungan yang positif dengan prestasi dalam subjek asas kewangan. 
Kajian bagi mengenal pasti faktor penentu prestasi pelajar perakaunan telah dilakukan oleh Waples dan Daraiseh (2005) yang menggunakan purata mata gred keseluruhan (PMK) untuk mengukur pencapaian prestasi terdahulu, dan kajian dapatan menunjukkan hubungan yang signifikan antara PMK dan prestasi pelajar. Mereka mendapati purata mata gred keseluruhan, gred dalam subjek perakaunan bagi semester terdahulu dan gred dalam subjek asas perakaunan pengurusan adalah signifikan bagi menentukan prestasi subjek perakaunan kewangan pertengahan.

\section{Pendedahan Awal}

Penemuan kajian terdahulu mendapati keputusan yang tidak konsisten berhubung dengan kesan pendedahan bagi bidang tertentu dengan pencapaian pelajar dalam bidang yang sama. Dalam bidang perakaunan, Delaney et al. (1979) mendapati hubungan positif antara keputusan ujian kemasukan bagi kursus perakaunan pertengahan dan prestasi dalam kursus tersebut. Kajian Eskew dan Faley (1988) juga menunjukkan pengetahuan dan pendedahan awal dalam bidang perakaunan dapat memberikan pencapaian yang lebih baik di peringkat pengajian yang lebih tinggi. Baldwin dan Howe (1982); dan Doran dan Bouillon (1991) pula mendapati pengetahuan dalam asas simpan kira dapat membantu prestasi pelajar di peringkat awal kursus perakaunan. Waples dan Darayseh (2005) turut bersetuju bahawa pendedahan awal dalam subjek perakaunan kewangan dan perakaunan pengurusan mempengaruhi prestasi dalam subjek perakaunan kewangan pertengahan. Walau bagaimanapun, Kruck dan Lending (2003) menunjukkan pertemuan yang berbeza berdasarkan pendedahan awal dalam kursus yang sama tidak memberi kesan yang signifikan terhadap prestasi pelajar yang mengambil kursus sistem maklumat.

\section{Jantina}

Dapatan kajian terdahulu juga menunjukkan jantina pelajar mempengaruhi prestasi pengajian mereka. Kajian ke atas pelajar universiti di Australia mendapati prestasi pelajar perempuan mengatasi pelajar lelaki (Birch \& Miller, 2007). Kajian oleh Borg dan Stranahan (2002) juga menunjukkan pelajar perempuan yang suka menyendiri memperoleh prestasi yang lebih baik berbanding dengan para pelajar lain bagi subjek ekonomi di peringkat lebih tinggi. Kajian yang di lakukan oleh Mutchler, Turner dan Williams (1987) dan Lipe (1989) menunjukkan prestasi pelajar perempuan jauh lebih baik berbanding dengan pelajar lelaki dalam subjek 
perakaunan. Manakala Doran dan Bouillon (1991) mendapati pelajar lelaki mendapat markah peperiksaan lebih baik berbanding pelajar perempuan dalam kursus "Accounting Principles I" tetapi sebaliknya, pelajar perempuan lebih cemerlang dalam peperiksaan “Accounting Principles II”. Walau bagaimanapun, kajian oleh Didia dan Hasnat (1998) dan Buckless, Lipe dan Ravenscroft (1991) mendapati jantina pelajar tidak mempengaruhi prestasi pelajar tersebut.

\section{Galakan}

Penglibatan ibu bapa penting dalam memberi motivasi untuk meningkatkan prestasi pelajar (Gonzalez-DeHass, Willems, \& Holbein, 2005). Walau bagaimanapun, Jemali (1988) mendapati prestasi pelajar di dalam ujian pencapaian Bahasa Inggeris tidak dipengaruhi oleh galakan ibu bapa dan guru.

\section{Sikap, Motivasi dan Usaha}

Kajian terdahulu juga menunjukkan pengukur sikap, usaha dan motivasi boleh menjelaskan perbezaan pencapaian akademik selain daripada yang dijelaskan oleh gred dan pengukur pencapaian akademik yang lain (Jemali, 1988; Grabe \& Latta, 1981; Urugolu \& Walberg, 1979; Wolfe, 1981; dan O’Donnell \& Preedy, 2001). Sikap yang cenderung kepada sesuatu subjek akan meningkatkan motivasi pelajar untuk terus berusaha bagi meningkatkan prestasi dalam subjek tersebut (Jemali, 1988). Menurut Papanastasiou (2000), pelajar yang mempunyai sikap yang positif terhadap matematik akan mendapat keputusan yang baik dalam subjek ini. Ahmad Fauzi, Wong dan Norhayati (2005) menyokong dapatan ini bagi subjek kalkulus.

Carbonaro (2005) merumuskan bahawa usaha pelajar memberi hubungan yang signifikan secara positif ke atas pencapaian prestasi. Gardner, Lalonde dan Moorcraft (1985) dalam kajiannya mengenai pembelajaran bahasa, mendefinisikan motivasi sebagai satu kombinasi antara usaha dan keinginan untuk mencapai matlamat. Perkara ini disokong oleh Kruck dan Lending (2003) yang menyatakan prestasi pelajar akan meningkat apabila pelajar mempunyai usaha/motivasi untuk mencapai keputusan yang baik bagi tugasan yang diberi.

Dalam bidang perakaunan sendiri terdapat beberapa kajian telah dibuat untuk melihat hubungan antara tahap usaha dan motivasi bagi menentukan pencapaian pelajar. Kajian Wooten (1998) kajian ke atas pelajar yang mengambil kursus asas 
perakaunan menunjukkan bahawa motivasi memberi pengaruh yang signifikan ke atas prestasi pelajar. Menurut beliau, motivasi dipengaruhi oleh tahap motivasi yang diukur melalui skala markah $0-100$, jangkaan markah pelajar dan suasana di dalam bilik darjah/ kuliah yang kondusif. Beliau juga mendapati pelajar-pelajar yang menjangka bahawa mereka akan mendapat markah yang tinggi dalam subjek perakaunan akan mempunyai motivasi yang tinggi. Para pelajar yang mempunyai motivasi yang tinggi akan berusaha untuk mencapai prestasi yang baik dalam subjek berkaitan. Maksy dan Lin Zheng (2008) juga menunjukkan gred yang dijangka akan diperoleh oleh pelajar mempunyai hubungan yang signifikan ke atas prestasi pelajar. Kajian Maksy dan Lin Zheng ini telah dijalankan ke atas 104 pelajar di sebuah universiti awam yang mengambil kursus perakaunan lanjutan dan pengauditan.

Kajian oleh Eskew dan Faley (1988) yang mengukur tahap motivasi/usaha pelajar melalui bilangan kuiz yang diambil dalam kursus perakaunan mendapati bahawa tahap motivasi/usaha mempengaruhi prestasi pelajar di dalam kursus tersebut. Melalui kajian Ibrahim (1989) ke atas prestasi pelajar dalam perakaunan pengurusan kos mendapati hubungan signifikan antara tahap usaha pelajar dengan prestasi sebenar. Tahap usaha pelajar di sini diukur daripada bilangan jam sebenar digunakan untuk mengulangkaji subjek berkenaan. Walau bagaimanapun, dalam kajian ke atas pelajar subjek asas kewangan, Didia dan Hasnat (1998) mendapati bilangan jam yang digunakan untuk mengulangkaji pelajaran mempunyai hubungan yang negatif dengan prestasi pelajar ke atas subjek berkenaan.

\section{METODOLOGI}

\section{Rangka dan Pemboleh ubah Kajian}

\section{Prestasi dalam subjek perakaunan pengurusan}

Kajian ini menggunakan prestasi sebenar iaitu markah akhir untuk subjek perakaunan pengurusan yang diperoleh oleh pelajar yang dipilih dalam sampel kajian sebagai pemboleh ubah bersandar (Maksy \& Li Zheng, 2008; Kruck \& Lending, 2003). Markah akhir pelajar yang terpilih dalam sampel di ambil daripada rekod markah pelajar matrikulasi yang telah disahkan. Skor markah untuk penilaian prestasi berada dalam julat 0 hingga 100. Makin tinggi markah pelajar, makin tinggi prestasi pencapaian mereka dalam subjek perakaunan. 


\section{Faktor penentu prestasi}

Berdasarkan kajian terdahulu, beberapa pemboleh ubah digunakan sebagai faktor penentu prestasi pelajar. Bagi menyesuaikan dengan situasi pelajar-pelajar di Malaysia, kajian ini mengambil kira pemboleh ubah tambahan yang dijangka dapat mempengaruhi prestasi pelajar iaitu sekolah terakhir pelajar (sama ada daripada sekolah berasrama penuh atau tidak). Jenis sekolah menengah yang dihadiri oleh pelajar dapat mempengaruhi prestasi pengajian mereka di peringkat seterusnya (Birch \& Miller, 2007). Disamping itu, pemboleh ubah lain yang digunakan dalam kajian ini ialah jangkaan program yang ingin diikuti oleh pelajar di peringkat ijazah dan ia dianggap sebagai dorongan kepada pelajar-pelajar untuk memperoleh keputusan yang baik di peringkat matrikulasi.

Jadual 1 menunjukkan pemboleh ubah-pemboleh ubah yang dikaji bagi menentukan faktor penentu prestasi dalam subjek perakaunan (pemboleh ubah) dan pengukurannya.

Jadual 1. Pemboleh ubah-pemboleh ubah dan Definisinya

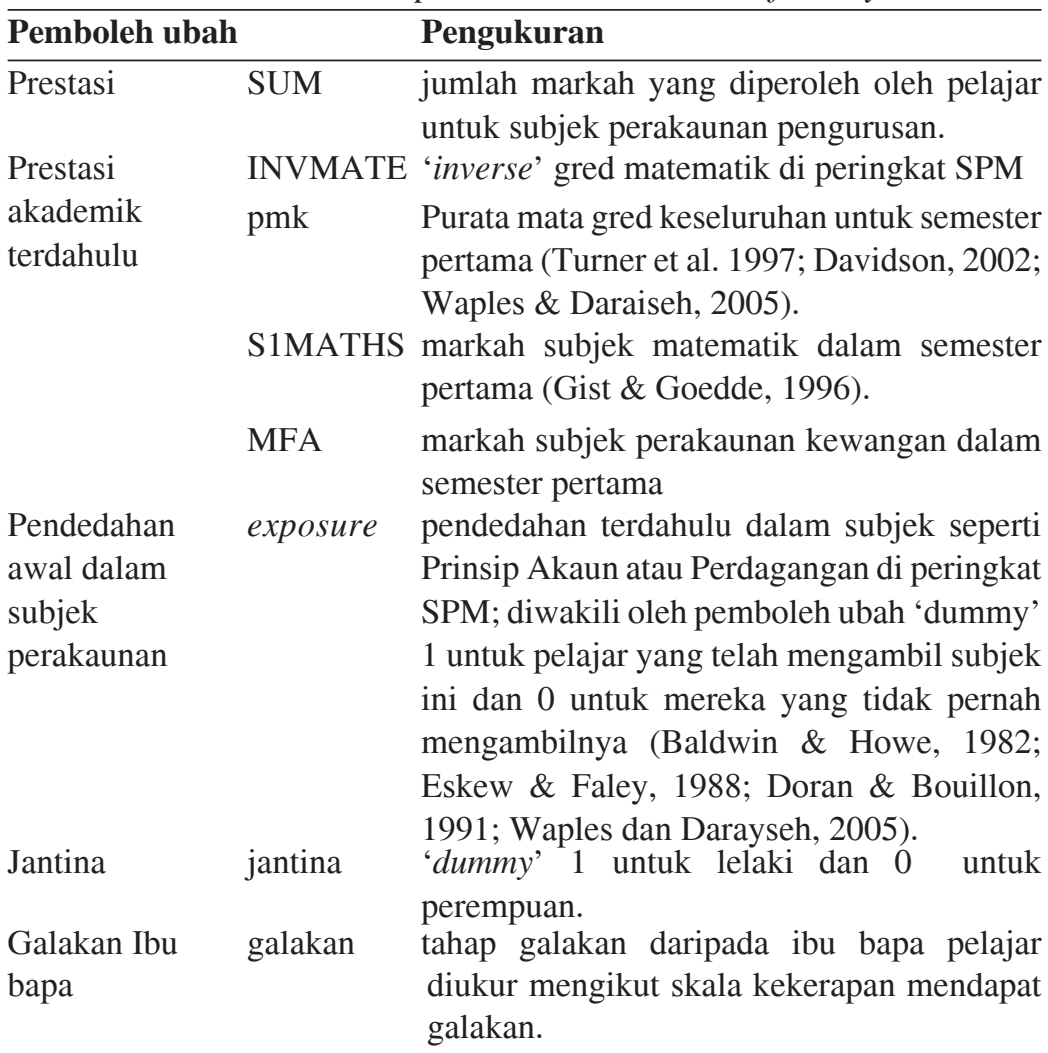


Jadual 1. (sambungan)

\begin{tabular}{|c|c|c|}
\hline \multicolumn{2}{|c|}{ Pemboleh ubah } & \multirow[b]{2}{*}{$\begin{array}{l}\text { Pengukuran } \\
\text { skala berdasarkan beberapa soalan berkaitan } \\
\text { sikap pelajar terhadap subjek perakaunan } \\
\text { (ubah suai daripada Ahmad Fauzi Mohd } \\
\text { Ayub, et al. 2005; Jemali, 1988; Grabe \& } \\
\text { Latta, 1981; Urugolu \& Walberg, 1979; } \\
\text { Wolfe, 1981; Wooten, 1998). }\end{array}$} \\
\hline Sikap pelajar & sikap & \\
\hline \multirow[t]{2}{*}{ Motivasi } & motivasi & $\begin{array}{l}\text { tahap motivasi diukur mengikut skala } \\
\text { berdasarkan beberapa soalan berkaitan (ubah } \\
\text { suai daripada Jemali, 1988). }\end{array}$ \\
\hline & jmot & $\begin{array}{l}\text { jangkaan tahap motivasi pelajar }(0-100) \\
\text { (Gardner, Lalonde \& Moorcraft,1985; } \\
\text { Wooten, 1998; Jemali, 1988). }\end{array}$ \\
\hline \multirow[t]{2}{*}{ Usaha } & usaha & $\begin{array}{l}\text { tahap usaha diukur mengikut skala } \\
\text { berdasarkan beberapa soalan berkaitan } \\
\text { termasuk purata jam dalam seminggu } \\
\text { digunakan untuk ulang kaji subjek } \\
\text { perakaunan (Ibrahim, 1989; Didia \& } \\
\text { Hasnat, 1998). }\end{array}$ \\
\hline & markah1 & $\begin{array}{l}\text { markah yang dijangka oleh pelajar diperoleh } \\
\text { untuk subjek ini. }\end{array}$ \\
\hline $\begin{array}{l}\text { Jangkaan } \\
\text { program }\end{array}$ & program & $\begin{array}{l}\text { pilihan utama program yang dijangka akan } \\
\text { diikuti di peringkat ijazah diwakili oleh } \\
\text { 'dummy' } 1 \text { untuk program perakaunan dan } 0 \\
\text { untuk program selain perakaunan. }\end{array}$ \\
\hline \multicolumn{2}{|c|}{ Sekolah terakhir sekolah } & $\begin{array}{l}\text { 'dummy' } 1 \text { untuk sekolah berasrama penuh } \\
\text { dan } 0 \text { untuk sekolah selain daripada sekolah } \\
\text { berasrama penuh. }\end{array}$ \\
\hline
\end{tabular}

\section{Sampel dan Data Kutipan}

Saiz sampel kajian ini terdiri daripada 450 orang pelajar matrikulasi. Jumlah ini mencukupi menurut Hair, Anderson, Tatham dan Black (2005) yang mencadangkan saiz sampel adalah antara 15 hingga 20 pemerhatian bagi setiap pemboleh ubah bebas apabila kaedah regresi digunakan dalam analisis data. Kajian ini mengambil kira 14 pemboleh ubah bebas, maka saiz sampel sepatutnya dalam julat 210 hingga 280 pelajar. Sampel dikatakan menggambarkan keseluruhan populasi jika tahap ini dapat dicapai (Hair et al., 2005). 
Borang soal selidik telah dibina untuk mengumpul data bagi setiap pemboleh ubah dan telah dilengkapkan oleh pelajar seminggu sebelum peperiksaan akhir semester. Tempoh ini dipilih kerana pelajar telah menduduki dan mengetahui keputusan peperiksaan pertengahan semester dan kerja kursus. Mereka sedang dalam minggu persediaan untuk menghadapi peperiksaan akhir (minggu ulang kaji). Ujian pilot telah dijalankan sebelumnya ke atas 25 orang pelajar. Hasil ujian kebolehpercayaan (berdasarkan "cronbach alpha") yang diuji bagi item-item galakan, sikap, motivasi dan usaha melebihi 0.80 . Nilai ini melebihi tahap minimum 0.70 yang diperlukan untuk mengesahkan kebolehpercayaan soalan-soalan di dalam borang soal-selidik (Sekaran, 2003).

Data dikumpul daripada sampel kajian yang terdiri daripada 450 orang pelajar yang mengambil subjek perakaunan pengurusan. Pelajar-pelajar tersebut dipilih daripada 13 kelas yang dikendalikan oleh sembilan orang guru daripada 27 orang guru perakaunan pengurusan keseluruhan bagi mengurangkan darjah kebergantungan ke atas cara atau kaedah pengajaran guru. Daripada 450 borang soal selidik ini, 57 soal selidik didapati tidak lengkap dan tidak diambilkira. Keseluruhan 393 sampel digunakan dalam kajian ini. Jadual 2 menunjukkan frekuensi sampel yang dipilih dipecahkan mengikut jantina pelajar.

Jadual 2. Frekuensi Pelajar Mengikut Jantina

\begin{tabular}{lcc}
\hline Jantina & Bilangan Pelajar & Peratus \\
\hline Lelaki & 115 & 29 \\
Perempuan & 278 & 71 \\
Jumlah & 393 & 100 \\
\hline
\end{tabular}

\section{ANALISIS DAN PENEMUAN}

\section{Prestasi Pencapaian Pelajar}

Jadual 3 menunjukkan peratusan markah pelajar sebagai sampel kajian. Peratusan markah ini berdasarkan sistem pemarkahan matrikulasi. Jadual 3 menunjukkan peratusan markah bagi gred Bke atas hanya $37.7 \%$ berbanding dengan gred $\mathrm{C}+$ dan ke bawah sebanyak $62.3 \%$. Agihan ini menunjukkan bukti kelemahan pelajar dalam subjek perakaunan. 
Jadual 3. Agihan Peratusan Markah Mengikut Jantina

\begin{tabular}{lcccc}
\hline & Lelaki & Perempuan & $\begin{array}{c}\text { Jumlah } \\
\text { Pelajar }\end{array}$ & Peratus \\
\hline A & 12 & 18 & 30 & 7.6 \\
B+ & 9 & 16 & 25 & 6.4 \\
B & 12 & 27 & 39 & 10.0 \\
B- & 12 & 42 & 54 & 13.7 \\
C+ & 15 & 42 & 57 & 14.5 \\
C & 17 & 47 & 64 & 16.3 \\
D+ & 17 & 37 & 54 & 13.7 \\
D & 12 & 36 & 48 & 12.2 \\
F & 9 & 13 & 22 & 5.6 \\
\hline Jumlah & 115 & 278 & 393 & 100 \\
\hline
\end{tabular}

Faktor berlainan jantina tidak dipisahkan kerana tidak banyak perbezaan di antara purata markah pelajar lelaki dengan pelajar perempuan (rujuk Jadual 4). Maka, tanpa mengambil kira faktor jantina, analisis telah dibuat dengan andaian semua data terdiri daripada populasi yang sama.

Jadual 4. Markah Mengikut Jantina

\begin{tabular}{lcccccc}
\hline Jantina & $\begin{array}{c}\text { Markah } \\
\text { minimum }\end{array}$ & $\begin{array}{c}\text { Markah } \\
\text { maksimum }\end{array}$ & $\begin{array}{c}\text { Purata } \\
\text { markah }\end{array}$ & Median & Sisihan & $\begin{array}{c}\text { Sisihan } \\
\text { Piawai }\end{array}$ \\
\hline Perempuan & 23.55 & 86.16 & 55.67 & 55.21 & 132.96 & 11.53 \\
Lelaki & 26.65 & 81.55 & 56.46 & 55.69 & 158.15 & 12.58 \\
\hline
\end{tabular}

Berdasarkan purata markah dalam Jadual 4, analisis menunjukkan tahap pencapaian pelajar bagi subjek perakaunan hanya dalam purata gred $\mathrm{C}$ sahaja. Agihan sampel mengikut jantina ini juga membuktikan pencapaian yang rendah dalam subjek ini.

\section{Faktor Penentu Prestasi Pelajar}

Data telah dianalisis menggunakan pakej SPSS untuk menguji hipotesis bagi menentukan hubungan di antara prestasi pelajar dalam subjek perakaunan pengurusan dengan 14 pemboleh ubah tidak bersandar yang telah diterangkan dalam bahagian metodologi. Dapatan melalui kaedah "stepwise" regresi berkali, menunjukkan nilai t bagi pemboleh ubah motivasi, jantina, program, galakan, sekolah terakhir adalah tidak signifikan. Oleh, itu model yang 
diterima hanya mengambil kira sembilan pemboleh ubah sahaja iaitu pencapaian matematik di peringkat SPM (INVMATE), pencapaian dalam subjek berkaitan iaitu perakaunan kewangan (MFA) dan dalam subjek matematik (S1MATHS) dalam semester terdahulu, pendedahan awal dalam bidang perakaunan (exposure), purata mata gred keseluruhan (pmk), markah yang dijangka oleh pelajar sendiri diperoleh untuk subjek perakaunan pengurusan (markah1), jangkaan tahap motivasi pelajar semasa mengikuti subjek perakaunan pengurusan (jmot), sikap (sikap) dan usaha (usaha) pelajar.

Matrik korelasi telah digunakan untuk menilai hubungan antara pemboleh ubah-pemboleh ubah dalam model ini. Merujuk kepada Jadual 5 bagi menilai 'intercorrelations' antara pemboleh ubah, pekali S1MATHS/pmk menunjukkan dapatan yang agak tinggi kerana pencapaian matematik semester pertama pelajar di peringkat matrikulasi diambilkira dalam pengiraan pmk pelajar semester berkenaan. Di samping itu, pekali MFA/pmk juga menunjukkan nilai yang tinggi kerana pencapaian bagi subjek perakaunan kewangan juga diambilkira dalam menentukan pmk. Hubungan antara matematik di peringkat SPM dan matrikulasi didapati signifikan dengan nilai pekali 0.65 kerana asas matematik yang kuat biasanya akan diikuti dengan pencapaian yang baik dalam subjek ini. Pekali usaha/sikap juga agak tinggi mungkin kerana sikap dan usaha selalunya seiring, apabila sikap seseorang itu positif, maka lebih banyaklah usahanya untuk mencapai sesuatu tujuan.

Jadual 5. Matrik Korelasi antara Pemboleh ubah-pemboleh ubah

\begin{tabular}{|c|c|c|c|c|c|c|c|c|c|c|}
\hline $\begin{array}{c}\text { Pemboleh- } \\
\text { Ubah }^{1}\end{array}$ & 1 & 2 & 3 & 4 & 5 & 6 & 7 & 8 & 9 & 10 \\
\hline 1.SUM & 1.00 & 0.47 *: & $0.73 * *$ & $0.66 * *$ & $0.77 *$ & $* 0.15 * *$ & $0.59 * *$ & $0.45^{* *}$ & $0.49 * *$ & $0.28 * *$ \\
\hline 2.INVMATE & & 1.00 & $0.49^{* *}$ & $0.65 * *$ & $=0.47 * *$ & * $0.11 *$ & $0.38 * *$ & $0.18 * *$ & $0.29 * *$ & $0.10 *$ \\
\hline 3.pmk & & & 1.00 & $0.79 * *$ & $0.77 * *$ & $* 0.16^{* *}$ & $0.47 * *$ & $0.27 * *$ & $0.36^{* *}$ & $0.26^{* *}$ \\
\hline 4.S1MATHS & & & & 1.00 & $0.67 * *$ & $* 0.10 *$ & $0.47 * *$ & $0.24 * *$ & $0.36 * *$ & $0.30^{* *}$ \\
\hline 5.MFA & & & & & 1.00 & $0.31 * *$ & $0.57 * *$ & $0.46^{* *}$ & $0.48 * *$ & $0.44 * *$ \\
\hline 6.exposure & & & & & & 1.00 & $0.18 * *$ & $0.19 * *$ & $0.15 * *$ & $0.11 *$ \\
\hline 7.markah1 & & & & & & & 1.00 & $0.47 * *$ & $0.55^{* *}$ & $0.61 * *$ \\
\hline 8.sikap & & & & & & & & 1.00 & $0.55 * *$ & $0.19 * *$ \\
\hline 9.jmot & & & & & & & & & 1.00 & $0.10^{*}$ \\
\hline 10.usaha & & & & & & & & & & 1.00 \\
\hline
\end{tabular}

** signifikan pada tahap 0.01 (2-tailed)

* signifikan pada tahap 0.05 (2 tailed)

${ }^{1}$ Definisi bagi SUM, INVMATE, pmk, SIMATHS, MFA, exposure, markah1, sikap, jmot dan usaha seperti dalam Jadual 1. 
Jadual 6 menunjukkan keputusan analisis regresi berkali. Dapatan kajian menunjukkan Sembilan pemboleh ubah model (INVMATE, MFA, S1MATHS, exposure, pmk, markah1, jmot, sikap dan usaha) memberi sumbangan dalam menerangkan variasi prestasi pelajar bagi subjek perakaunan pengurusan iaitu $\mathrm{R}^{2}=0.69$ dan $\mathrm{p}<0.00$. Keputusan ini konsisten dengan penemuan Eskew dan Faley (1988) iaitu pemboleh ubah seperti SAT sebagai pengukur pencapaian terdahulu, bilangan kuiz yang diambil sebagai pengukur usaha, pendedahan awal dalam subjek perakaunan, pendedahan awal dan prestasi terdahulu dalam subjek berkaitan menerangkan variasi signifikan dalam keputusan pelajar $\left(\mathrm{R}^{2}=0.54, \mathrm{p}<0.001\right)$. Nilai $\mathrm{R}^{2}$ terselaras dikira menggunakan formula pembetulan statistik yang menunjukkan nilai 0.682 tiada perbezaan ketara dalam sampel yang digunakan dalam model ini.

Jadual 6. Keputusan Analisis Regresi Berkali

$$
\text { Model Kajian : } \begin{aligned}
\mathrm{SUM}_{\mathrm{i}}=\mathrm{b}_{0} & +\mathrm{b}_{1} \text { INVMATE }+\mathrm{b}_{2} \text { pmk }+\mathrm{b}_{3} \text { S1MATHS } \\
& +\mathrm{b}_{4} \text { MFA }+\mathrm{b}_{5} \text { exposure }+\mathrm{b}_{6} \text { markah } 1+ \\
& \mathrm{b}_{7} \text { sikap }+\mathrm{b}_{8} \text { jmot }+\mathrm{b}_{9} \text { usaha }+e_{i}
\end{aligned}
$$

\begin{tabular}{llccccc}
\hline Pemboleh ubah & Pekali & $\begin{array}{c}\text { Sisihan } \\
\text { Piawai }\end{array}$ & Beta & Nilai t Signifikan & $\begin{array}{c}\text { 'Variance } \\
\text { Inflation } \\
\text { Factor' }\end{array}$ \\
\hline INVMATE & 1.84 & 1.42 & 0.05 & 1.29 & 0.20 & 1.79 \\
Pmk & 7.36 & 1.50 & 0.28 & 4.90 & $0.00^{*}$ & 3.70 \\
S1MATHS & $6.489 \mathrm{E}-02$ & 0.05 & 0.08 & 1.39 & 0.17 & 3.54 \\
MFA & 0.36 & 0.06 & 0.35 & 6.44 & $0.00^{*}$ & 3.39 \\
exposure & -2.56 & 1.08 & -0.07 & -2.37 & $0.02^{* *}$ & 1.14 \\
markah1 & 0.12 & 0.04 & 0.12 & 2.99 & $0.00^{*}$ & 1.86 \\
Sikap & 0.26 & 0.12 & 0.09 & 2.11 & $0.04 * *$ & 2.16 \\
Jmot & $5.093 \mathrm{E}-02$ & 0.03 & 0.08 & 1.91 & $006 * *$ & 1.80 \\
Usaha & 0.22 & 0.22 & 0.04 & 1.00 & 0.32 & 1.73 \\
\hline
\end{tabular}

$\mathrm{R}^{2}=0.69 \quad \mathrm{R}^{2}$ Terlaras $=0.68 \quad$ Nilai $\mathrm{F}=89.52 \quad$ Signifikan $\mathrm{F}=0.00$

** signifikan pada tahap 0.0001

* signifikan pada tahap 0.01

${ }^{1}$ Definisi bagi SUM, INVMATE, pmk, SIMATHS, MFA, exposure, markah1, sikap, jmot dan usaha seperti dalam Jadual 1.

2 Nilai VIF kurang daripada 10 menunjukkan tiada masalah 'multicollinearity' (Neter, Wasserman \& Kutner, 1985). 
Nilai beta $(\beta)$ terselaras bagi setiap pemboleh ubah ditunjukkan dalam kolum 4 Jadual 6 . Semua beta menunjukkan nilai positif kecuali bagi pendedahan awal. Nilai positif ini konsisten seperti jangkaan kerana semua pemboleh ubah tidak bersandar akan memberi kesan positif ke atas prestasi pelajar (Eskew \& Faley, 1988; Doran \& Bouillon, 1991). Merujuk kepada Jadual 6, daripada pemboleh ubah tidak bersandar yang diambilkira di dalam model, pemboleh ubah yang paling signifikan dan berhubungan positif $(\mathrm{p}<0.00)$ bagi menentukan pencapaian pelajar adalah pencapaian terdahulu pelajar iaitu markah perakaunan kewangan (MFA) dan purata mata gred keseluruhan (pmk). Markah yang dijangka diperoleh oleh pelajar untuk subjek perakaunan pengurusan (markah1) juga memberikan sumbangan signifikan dan positif bagi menerangkan variasi prestasi pencapaian pelajar.

Faktor pendedahan awal (exposure) dalam subjek perakaunan juga menunjukkan nilai signifikan tetapi berhubungan negatif. Hubungan songsang ini bertentangan dengan hasil kajian Eskew dan Faley (1988), iaitu hasil menunjukkan pelajar yang telah mendapat pendedahan awal dalam subjek perakaunan tidak menunjukkan prestasi yang baik berbanding dengan pelajar yang belum pernah didedahkan dengan subjek perakaunan. Jumlah skor ke atas proksi yang digunakan untuk mengukur sikap pelajar dalam mempelajari subjek perakaunan juga menunjukkan hubungan positif yang signifikan. Tahap motivasi yang dijangkakan oleh pelajar semasa mengikuti subjek ini juga berhubungan positif dan signifikan. Manakala markah subjek berkaitan seperti markah matematik sebenar yang diperoleh pelajar dalam semester pertama di peringkat matrikulasi dan juga di peringkat SPM tidak signifikan untuk menerangkan variasi prestasi pencapaian pelajar. Tahap usaha pelajar menunjukkan nilai paling tidak signifikan dalam menentukan pencapaian pelajar dalam subjek perakaunan.

\section{PERBINCANGAN}

Kajian ini tertumpu kepada penilaian ke atas faktor-faktor penentu prestasi pelajar bagi subjek perakaunan peringkat matrikulasi. Berpandukan kepada kajian terdahulu dan situasi pelajar di Malaysia, kajian ini mengenal pasti 14 pemboleh ubah sebagai penentu prestasi. Bagaimanapun, melalui kaedah "stepwise" regresi berkali, hanya 9 pemboleh ubah yang diterima pakai dalam model. 
Pemboleh ubah kebolehan atau pengetahuan asas dalam bidang perakaunan dan juga pencapaian akademik terdahulu dilihat sebagai penentu utama kepada prestasi atau pencapaian pelajar dalam subjek perakaunan. Keputusan ini selari dengan kajian yang dibuat oleh Turner et al. (1997), Maksy dan Lin Zheng (2008); dan Waples dan Daraiseh (2005). Hasil kajian bagaimanapun menunjukkan bahawa prestasi terdahulu dalam kursus matematik tidak memberi kesan bagi prestasi perakaunan. Selain daripada faktor akademik, penemuan kajian juga menunjukkan adanya hubungan signifikan antara faktor lain seperti sikap, motivasi dan jangkaan markah. Secara umum, kajian ini menyokong dapatan kajian terdahulu, bahawa prestasi akademik terdahulu bukan sahaja merupakan faktor penentu prestasi tetapi sikap dan motivasi juga adalah penting untuk dititikberatkan (Maksy \& Lin Zheng, 2008).

Penemuan kajian juga menunjukkan hubungan antara pendedahan awal dengan pencapaian prestasi adalah negatif iaitu berhubungan songsang. Pelajar yang mempunyai pendedahan awal menunjukkan prestasi yang rendah berbanding dengan pelajar yang tiada pendedahan awal. Dapatan ini bertentangan dengan hasil kajian terdahulu yang dilakukan oleh Waples dan Daraiseh (2005); Delaney et al. (1979); Baldwin dan Howe (1982); Eskew dan Faley (1988), dan Doran dan Bouillon (1991) yang menunjukkan kesan positif. Dapatan menunjukkan mereka yang mempunyai pendedahan awal merasakan rangka kursus yang sedia ada mempunyai banyak persamaan dengan pendedahan terdahulu. Maka, mereka akan merasa cepat bosan dan mengambil sikap sambil lewa. Andaian ini menyebabkan mereka tidak dapat menunjukkan prestasi yang lebih baik.

Dapatan kajian ini diharapkan dapat membantu pihak pelajar, guru-guru dan pihak pentadbiran matrikulasi dan universiti membuat perancangan dan sebarang tindakan. Para pelajar boleh menggunakan faktor-faktor seperti prestasi terdahulu untuk membuat perancangan akademik di masa hadapan (misalnya, pilihan untuk mengikuti program perakaunan). Guru-guru juga boleh menggunakan faktorfaktor penentu prestasi untuk menentukan kaedah pengajaran mereka. Misalnya, kaedah yang digunakan dalam pengajaran bagi para pelajar yang telah mempunyai pendedahan awal mungkin berbeza dengan pelajar yang tiada pendedahan awal. Pihak pentadbiran program matrikulasi juga boleh menggunakan faktor-faktor penentu ini untuk menyemak semula syarat kemasukan pelajar ke program di peringkat matrikulasi dan ijazah di samping merangka kurikulum. 
Pihak universiti juga perlu menekankan kursus-kursus motivasi yang boleh membantu meningkatkan prestasi pelajar.

Perbezaan tanggapan dan pandangan bagi isu yang dipersoalkan di dalam soal selidik dapat dikurangkan sekiranya peluang diberikan kepada pelajar untuk menyatakan pandangan mereka semasa perbincangan atau melalui temuduga. Kajian seterusnya boleh dijalankan bagi menentukan prestasi pelajar dengan mengambil kira faktor lain seperti kaedah pembelajaran, latar belakang keluarga dan kaedah pengajaran guru.

\section{RUJUKAN}

Ahmad Fauzi Mohd Ayub, Wong Su Lian \& Norhayati Mukti (2005). Students' attitudes toward calculus: A preliminary study among diploma students at Universiti Putra Malaysia. Jurnal Teknologi, 42(e) Jun, 49-60

Baldwin, B.A., \& Howe K. R. (1982). Secondary-Level study of accounting and subsequent performance in the first college course. The Accounting Review, 57(3), 619-626.

Birch, E. R. \& Miller, P. W. (2007). The influence of type of high school attended on university performance. Australian Economic Papers, 46(1), 1-17.

Borg, M. O., \& Stranahan, H. A. (2002). Personality type and student performance in upper-level economics courses: The importance of race and gender. Journal of Economic Education, 33, 3-14.

Buckles, F. A., Lipe, M. G., \& Ravenscroft, S. P. (1991). Do gender effects on accounting course performance persist after controlling for general academic aptitude? Issues in Accounting Education, 6(2), 248-261.

Carbonaro, W. (2005). Tracking, students' effort, and academic achievement. Sociology of Education, 78, 27-49.

Davidson, R. A. (2002). Relationship of study approach and exam performance. Journal of Accounting Education, 20 (1), 29-44.

Delaney, P. R., Keys, D. E., Norton, C. L. \& Simon, J. R. (1979). An admission test for Intermediate Accounting, The Accounting Review, (January), 155-162.

Didia, D. \& Hasnat, B. (1998). The determinants of performance in the University Introductory Finance Course. Financial Practice \& Education, Spring/Summer, 8(1), 102-107. 
Doran, B. M. \& Bouillon, M. L. (1991). Determinants of student performance in Accounting Principles I and II. Issues in Accounting Education, 6(1), 74-85.

Eskew, R. K. \& Faley, R. H. (1988). Some determinants of student performance in the first college-level Financial Accounting Course. The Accounting Review, 63(1), 137-147.

Gardner, R. C., Lalonde, R. N. \& Moorcraft, R. (1985). The role of attitudes and motivation in second language learning: Correlational and experimental considerations. Language Learning, 35, 207-227.

Gist, W.E \& Goedde, H. (1996). The influence of mathematical skills and other factors on minority student performance in Principles of Accounting. Issues in Accounting Education, 11(1), 49-61.

Gonzalez-DeHass, A. R., Willems, P. A., \& Holbein, M. F. D. (2005). Examining the relationship between parental involvement and student motivation. Educational Psychology Review, 17, 95-119.

Grabe, M., \&. Latta, R. M (1981). Cumulative achievement in a Mastery Instructional System: The impact of differences in resultant achievement motivation and persistence. American Educational Research Journal, 18(1), 7-13.

Hair, J. F., Anderson, R. E., Tatham, R. L. \& Black, W. C. (2005). Multivariate data analysis (6th ed.). Englewood Cliffs, New Jersey: Prentice Hall.

Hicks, D. W., \& Richardson, F. M. (1984). Predicting early success in Intermediate Accounting: the influence of entry examination and GPA. Issues in Accounting Education, 61-67.

Ibrahim, M. E. (1989). Effort-expectation and academic performance in Managerial Cost Accounting. Journal of Accounting Education, 7(1), 57-68.

Jemali, I. (1988). Exposure, attitudes, motivation and achievement in ESL among Malay learners: A Socio-Psycholinguistic Study. The British Library, West Yorkshire.

Kruck, S.E. \& Lending, D. (2003). Predicting academic performance in an introductory college-level IS course. Information Technology, Learning, and Performance Journal, 21(2), 9-15.

Lipe, M. G. (1989). Further evidence on the performance of female versus male students. Issues in Accounting Education,4(1), 144-152. 
Maksy, M. M. \& Lin Zheng (2008). Factors associated with student performance in advanced accounting and auditing - an empirical study in a public university. Accounting Research Journal, 21(1), 16-32.

McKenzie K. \& Schweitzer, R. (2001). Who succeeds at university? Factors predicting academic performance in first year Australian university students. Higher Education Research \& Development, 20(1), 21-33.

Mutchler, J. F., Turner, J. H. \& Williams, D. D. (1987). The performance of female versus male accounting students. Issues in Accounting Education,2(1), 103-111.

Neter, J., Wasserman, W. \& Kutner, M. (1985). Applied Linear Statistical Models. Homewood: Irwin.

O'Donnell, M. \& Preedy, M. (2001). Taking Action to Improve Students' Attitudes and Motivation. Management in Education, 15(5), 25.

Papanastasiou, C. (2000). Effects of attitudes and beliefs on mathematics achievement. Studies in Educational Evaluation, 26(1) 27-42.

Richter, A. (2006). Intertemporal consistency of predictors of student performance: evidence from a Business Administration Program. Journal of Education for Business. 82(2), 88-93.

Sekaran, U. (2003). Research Methods for Business: A skill building approac (4th ed.). New York: John Wiley and Sons.

Turner, J. L., Holmes, S.A. \& Wiggins, C.E. (1997). Factors associated with grades in Intermediate Accounting. Journal of Accounting Education, 15 (2), 269-288.

Urugolu, M. E., \& Walberg, H. J. (1979). Motivation and achievement: A quantitative synthesis. American Education Research Journal, 16(4), 375-389.

Waples, E. \& Daraiseh, M. (2005). Determinants of students' performance in Intermediate Accounting. Journal of College Teaching \& Learning, 2(12), 87-91

Wolfe, M. L. (1981). Forecasting summative evaluation from formative evaluation: A double cross-validation study. Psychological Reports, 49, 843-848.

Wooten, T. C. (1998). Factors influencing student learning in Introductory Accounting classes: A comparison of traditional and nontraditional students. Issues in Accounting Education, 13 (2), 357-373. 